\title{
Chemical composition and liberation characterization of printed circuit board comminution fines for beneficiation investigations
}

\author{
I.O. Ogunniyi *, M.K.G. Vermaak, D.R. Groot \\ Department of Materials Science and Metallurgical Engineering, University of Pretoria, Mineral Sc. Building, Hatfield, Pretoria 0002, South Africa
}

\section{A R T I C L E I N F O}

\section{Article history:}

Accepted 3 March 2009

Available online $\mathrm{xxx}$

\begin{abstract}
A B S T R A C T
Chemical composition and liberation are critical attributes in characterizing a resource stock for beneficiation investigations. Though end-of-life printed circuit board is recognized as a valuable secondary resource stock, no procedural standard exists for the determination of its chemical composition, nor for the $-75 \mu \mathrm{m}$ fines generated during its comminution. The effect of the digestion procedure on the final assays in wet spectroscopic analyses was assessed in this work. Liberation was also explored against literature background. Determination of assays of all constituent elements in printed circuit board comminution fines was found to require comparison of data from more than one digestion condition, while composite particles still persist at the fines sizes, though very few. The discussion reflects how these impact the beneficiation investigations.
\end{abstract}

(c) 2009 Elsevier Ltd. All rights reserved.

\section{Introduction}

Physical processing of end-of-life (eol) printed circuit boards for resource recovery entails stage-wise comminution separation of the material values present on the populated boards into different streams. Among other merits, physical processing is recognized as the most environmentally friendly route for eol printed circuit boards processing (Goosey and Kellner, 2002; Mou et al., 2004). A major challenge to this operation is the poor recovery of base and precious metal values which reports to the $-75 \mu \mathrm{m}$ fraction generated during the comminution (Goosey and Kellner, 2002; Zhao et al., 2004; Ogunniyi and Vermaak, 2007). To avoid these losses, some operations prefer to avoid physical processing as much as possible and incinerate the whole feed stream (Goosey and Kellner, 2002), despite the off gas handling problems or the hazard of releasing toxic furans, dioxins and noxious gases (Nourreddine et al., 1998; D'Silva, 2004). Investigation of more efficient beneficiation technique for value recovery from these fines fraction is obviously a better approach to this problem, and froth flotation in particular has been suggested in this regard (Ogunniyi and Vermaak, 2007, 2009). However, more than fifteen assorted base and precious metal values can be expected in eol printed circuit boards comminution fines. Table 1 shows some representative printed circuit boards material compositions. While natural mineral deposits with three target values are considered complex orebodies (Wills, 1997), the complexity of printed circuit board comminution fines is obvious. This makes chemical composition for reliable material balance and recovery analysis, a critical

\footnotetext{
* Corresponding author. Tel.: +27 766216295; fax: +27 123625304

E-mail addresses: mrolatunji@tuks.co.za, mrolatunji@yahoo.com (I.O. Ogunniyi).
}

attribute in the characterization of the fine sample for beneficiation investigations. The degree of liberation is also critical as it determines achievable selectivity.

Composition determination of printed circuit boards comminution fines can be considered the same as for the whole board, since the board is also first pulverized for composition analysis. However, for eol populated printed circuit boards as a resource stock, procedure for its compositional analysis is rare in standard references (ASTM; ASTM, 2007; ISO). For such a stock, containing plastics, metals, alloys and ceramics, the composition analysis would ideally demand a wide range of analytical techniques, from spectroscopic to gravimetric. Reviews and investigations on eol printed circuit boards have mentioned techniques such as AAS, ICP-OES, ICP-MS, fire assay, XRF and XRD as applicable (Legarth et al., 1995; Zhang and Forssberg, 1997; Li et al., 2004). Generally, spectroscopic techniques - X-rays, flame, plasma, infra-red - can give good qualitative information, but for quantitative analysis, every source of error (sampling, digestion, dilution, calibration, interference, etc.) can be of very detrimental effect with such highly heterogeneous sample. Given the complexity of printed circuit boards, it is necessary to establish the effectiveness and limitation of each of these techniques and procedures for this sample. The work presented herein is focussed on the wet spectroscopy.

Common to wet spectroscopic methods such as AAS, ICP-OES and ICP-MS, is the fact that the final assay value can depend on the extent of leaching recovery into the analysis liquor, which in turn depends on the digestion procedure and reagents. To achieve total digestion of samples, increasingly aggressive reagents and environment are used, with aqua regia, hydrogen fluoride (HF) and microwave digestion being on the extremes. Aqua regia will digest almost all base metals and noble metals like gold. $\mathrm{HF}+\mathrm{HNO}_{3}$ 
Table 1

Representative material compositions of printed circuit boards (wt\%).

\begin{tabular}{|c|c|c|c|c|c|c|c|}
\hline Materials & $\%$ & $\%$ & $\% \mathrm{c}$ & $\%{ }^{\mathrm{d}, *}$ & $\%{ }^{\mathrm{e}}$ & $\%^{f}$ & $\%^{\mathrm{g}}$ \\
\hline \multicolumn{8}{|l|}{ Metals (Max. 40\%) } \\
\hline $\mathrm{Cu}$ & 20 & 26.8 & 10 & 15.6 & 22 & 17.85 & 23.47 \\
\hline $\mathrm{Al}$ & 2 & 4.7 & 7 & - & - & 4.78 & 1.33 \\
\hline $\mathrm{Pb}$ & 2 & - & 1.2 & 1.35 & 1.55 & 4.19 & 0.99 \\
\hline $\mathrm{Zn}$ & 1 & 1.5 & 1.6 & 0.16 & - & 2.17 & 1.51 \\
\hline $\mathrm{Ni}$ & 2 & 0.47 & 0.85 & 0.28 & 0.32 & 1.63 & 2.35 \\
\hline $\mathrm{Fe}$ & 8 & 5.3 & - & 1.4 & 3.6 & 2.0 & 1.22 \\
\hline Sn & 4 & 1.0 & - & 3.24 & 2.6 & 5.28 & 1.54 \\
\hline $\mathrm{Sb}$ & 0.4 & 0.06 & - & - & - & - & - \\
\hline $\mathrm{Au} / \mathrm{ppm}$ & 1000 & 80 & 280 & 420 & 350 & 350 & 570 \\
\hline $\mathrm{Pt} / \mathrm{ppm}$ & - & - & - & - & - & 4.6 & 30 \\
\hline $\mathrm{Ag} / \mathrm{ppm}$ & 2000 & 3300 & 110 & 1240 & - & 1300 & 3301 \\
\hline $\mathrm{Pd} / \mathrm{ppm}$ & 50 & - & - & 10 & - & 250 & 294 \\
\hline \multicolumn{8}{|l|}{ Ceramic (Max 30\%) } \\
\hline $\mathrm{SiO}_{2}$ & 15 & 15 & & 41.86 & 30 & - & - \\
\hline $\mathrm{Al}_{2} \mathrm{O}_{3}$ & 6 & - & - & 6.97 & - & & \\
\hline Alkaline and Alkaline earth oxides & 6 & - & - & $\begin{array}{l}\mathrm{CaO} 9.95 \\
\mathrm{MgO} 0.48\end{array}$ & - & & \\
\hline Titanates, Mica, etc. & 3 & - & - & - & - & - & - \\
\hline \multicolumn{8}{|l|}{ Plastics (Max 30\%) } \\
\hline Polyethylene & 9.9 & - & - & & 16 & - & - \\
\hline Polypropylene & 4.8 & & & & & & \\
\hline Polyesters & 4.8 & & & & & & \\
\hline Epoxies & 4.8 & & & & & & \\
\hline Polyvinyl-chloride & 2.4 & & & & & & \\
\hline Polytetra-flouroethane & 2.4 & & & & & & \\
\hline Nylon & 0.9 & & & & & & \\
\hline
\end{tabular}

\footnotetext{
a Shuey et al. (2006) from Sum (1991).

b Zhao et al. (2004).

c Zhang and Forssberg (1997).

d Kim et al. (2004).

e Iji and Yokoyama (1997).

${ }^{f}$ Kogan (2006).

g ICP-OES Analyses of cellphone printed circuit boards with hot aqua regia digestion.

Incinerated printed circuit boards Product.
}

provide the strongest chemical complexation and solubilisation power, dissolving virtually any matrix (Babara, 2003). $\mathrm{HNO}_{3}+$ microwave energy also provide high energy system that can also achieve total solubilisation in a less hazardous system compared to employing HF. For printed circuit boards, reported procedures have used aqua regia or other mixed acids (Zhang and Forssberg, 1997; Dunn and Nicholas, 1998). This digestion condition recovers part of constituents into the filtrate with glass fibre and plastics in residue. With such partial digestion, total recovery of all the target analytes in the sample may not be assumed, and the final assay can therefore be less than the actual or absolute value. A comparative reading of aliquots obtained from the aqua regia partial digestion and more aggressive procedures that will give total digestion can be more informative about the absolute assays of each the elements.

In respect of liberation in printed circuit boards comminution products, a high degree is commonly reported. The physical joineries on the boards are, to a large extent, effectively broken by the combination of stress modes in the mills commonly employed. Low speed high torque shear shredders are basically ideal for the primary crushing, while a number of mills have been reported for the finer comminution (Iji and Yokoyama, 1997; Zhang and Forssberg, 1999; Mou et al., 2004), with the swing hammer types appearing to have become the industry standard (Goosey and Kellner, 2003; hamos GmbH; Sander et al., 2004; Schubert and Bernotat, 2004). Schubert and Bernotat (2004) gave a good review of the different modifications of the swing hammer mills; the comminution mechanism is essentially the same. It breaks mostly by impact, with shear, compression and abrasion; a combination of stress modes appropriate for the diverse material types, from brittle to ductile, present on printed circuit boards. The product discharges through a screen - basically, a closed circuit grinding. As said, the degree of liberation from the grinding is generally very high. $100 \%$ liberation has been said to be achieved for major metal alloys at $600 \mu \mathrm{m}$ from hammer mill comminution (Zhang and Forssberg, 1997). Wen et al. (2005), also using hammer mill, reported that degree of metal liberation of printed wiring boards (another nomenclature for printed circuit boards) approaches $100 \%$ with decreasing size, and that the ideal size for liberation is $500 \mu \mathrm{m}$. In another work (Zhao et al., 2004), 100\% liberation was reported for copper from $-250 \mu \mathrm{m}$ fraction of hammer mill grinding. It basically follows that each particle in the $-75 \mu \mathrm{m}$ fraction will be made of totally liberated sole material. It is necessary to be sure of this broad inference, particularly for beneficiation investigation via froth flotation. That is, it is necessary to establish whether composite (unliberated) particles still persist at this size range.

From this background, this paper reports investigations of the effect of digestion procedure on final assay values of printed circuit boards comminution fines in wet spectroscopic analysis. Qualitative liberation assessment of polished sections of the comminution fines samples employing light microscope and scanning electron microscope is also reported.

\section{Methodology}

\subsection{Sample generation}

Large assortment of populated eol printed circuit boards, about $250 \mathrm{~kg}$ in all, from PCs, cell phones and switchboards were obtained. The PC boards mostly spanned 1989-2002, PI-PIV, Cyrix, Intel Celeron, IBM, Octek, Socket 3, 7, 8. Most of the boards are 
multilayer (with maximum of 4-layers), with few older single sided types. Components such as capacitors, liquid crystal displays and batteries which are usually rich in hazardous substances (Cui and Forssberg, 2003; EU, 2003) were first removed from the boards before comminution. The boards were first cut with a bench guillotine (employing a shearing action as in shear shredders) into roughly $4 \times 6 \mathrm{~cm}$ fragments appropriate for the choke of the swing hammer mill (Eriez magnetics MACSA Pedestal Type Model 300) used for the fine crushing and grinding. The comminution was basically as a result of impact, with shear, compression and abrasion, until comminution products get below the screen size in at least two of its dimensions and favorably oriented to pass through. The size reduction was done in stages, starting from $20 \mathrm{~mm}$ closed fine crushing. Product from this stage was screen classified, and the $-13,200 \mu \mathrm{m}+1180 \mu \mathrm{m}$ fraction was removed from the stream being more of sufficiently liberated metallic and plastic pieces amenable to eddy current separation, gravity air classifier, magnetic separation, etc. The $+13200 \mu \mathrm{m}$ fraction containing almost bare board fragments go through closed comminution again at $8 \mathrm{~mm}, 5 \mathrm{~mm}$ and $2 \mathrm{~mm}$ screens to liberate copper traces, solders still locked in the board vias, pin insertions, board fibres, resins, etc. The $-1180 \mu \mathrm{m}$ fraction from the first stage was mixed with the final product from the $2 \mathrm{~mm}$ grinding. The $-75 \mu \mathrm{m}$ fraction was screened from the final $-2 \mathrm{~mm}$ fraction. The total $-75 \mathrm{um}$ fraction actually gave about $85 \%$ and $65 \%$ passing $53 \mu \mathrm{m}$ and 38 $\mu \mathrm{m}$, respectively.

\subsection{Composition determination}

The total fines sample generated was split down in stages, and roughly $50 \mathrm{~g}$ true split sample was taken, from which samples for all the investigations were finally taken after thorough mixing. This is to eliminate sampling error as much as possible. A combination of reagent and environment to achieve total digestion was first sought. Hot aqua regia and two other aggressive combinations were considered: $\mathrm{HNO}_{3}+\mathrm{HF}+$ microwave, and sodium peroxide fusion followed by $\mathrm{HCl}$ dissolution. The three conditions were designated as AR, HHM and SPF, respectively. $1 \mathrm{~g}$ sample was taken for AR and HHM digestion, while the recipe for SPF is $0.5 \mathrm{~g}$ sample with 3.0 g sodium peroxide plus $1.5 \mathrm{~g}$ sodium carbonate. The mixture was heated over a gas flame in a zirconium crucible, and the fused sample digested totally in concentrated $\mathrm{HCl}$ solution $(25 \mathrm{ml}$ of $32 \% \mathrm{AR} \mathrm{HCl}$ in $100 \mathrm{ml}$ deionised $\mathrm{H}_{2} \mathrm{O}$ ). Details of the digestion techniques can be found in literatures (Babara, 2003; Henryk Matusiewicz, 2003). Digestion for each condition was done in duplicates, and filtration of undigested residue was done to obtain the analysis liquor when necessary. Inductively coupled plasma-optical emission spectroscopy reading was done for each solution in triplicate and averaged. Inductive coupled plasma-mass spectroscopy was used to analyse for $\mathrm{Au}, \mathrm{Ag}$, Pt and Pd separately with solutions from AR and HHM only, also as average of triplicate readings over duplicate samples. SPF solution was not analysed for the precious metals (explanation in results below).

\subsection{Liberation assessment}

Qualitative liberation assessment of the fines was done by examining polished sections of the sample in two size ranges of $-75+38 \mu \mathrm{m}$ and $-38 \mu \mathrm{m}$. Complementary observations were done with Nikon Eclipse ME600 light microscope and Jeol JSM 6300 scanning electron microscope. The electron microscope was operated at $30 \mathrm{keV}$ to generate all useful lines under energy dispersive X-ray spectroscopy mode. To enhance contrast between organic particles in the sample and the mounting medium in back-scattered electron mode, iodoform was embedded in the mounting resin. This increases the electron density of the mount- ing medium compared to the plastic particles. The iodoform, $10 \%$ by weight of resin plus hardener (Gomez et al., 1984), is first dissolved in the resin before adding the hardener. The resin and hardener used - Eli-CAST FRF 676 - is a cold setting combination products of Elite chemicals. The resin was selected as it uses a slow hardener to prevent vigorous exothermic reaction with iodoform which is a hazard with faster hardener systems.

\section{Results and discussion}

\subsection{Comparative wet assaying}

Only SPF digestion condition, sodium peroxide $\left(\mathrm{Na}_{2} \mathrm{O}_{2}\right)$ fusion followed by $\mathrm{HCl}$ dissolution, achieved total digestion of the sample, while $\mathrm{AR}$ (aqua regia) and $\mathrm{HHM}\left(\mathrm{HF}+\mathrm{HNO}_{3}\right.$ plus microwave) gave only partial digestions. Table 2 shows the assay values for 42 elements from the three digestion conditions. These assays are averages for duplicate digestions. The repeatability was around $95 \%$ for most elements, but $90 \%$ was also noted for some. This is considered acceptable recognising that a perfect replicate sample with such highly heterogeneous stock may not be realistic. Detailed analysis of sampling variance, element by element, over reasonably large population of sample, can be informative in this connection, but not within the present scope.

It should be noted that the assays in Table 2 are for printed circuit boards comminution fines and does not represent complete board analysis as in Table 1. Generally, metallic values deportment to the finer fractions in the comminution operation is lower than in the coarser fractions, as metallic materials are generally ductile and do not shatter into fines during comminution. Also, it will be noted that many elements including $\mathrm{Au}, \mathrm{Ag}, \mathrm{Pd}, \mathrm{Sb}, \mathrm{Sn}$, and $\mathrm{Zr}$ were not read from the total digestion solution from SPF. This is because of possible pronounced matrix effect on these elements under the optical emission spectroscopy (Willard et al., 1988). Hence, only solution from AR and HHM conditions were analysed for all the 42 elements.

From the data, Si gave distinctly highest value, 10 times higher, under SPF compared to AR and HHM. These result from the digestion of glass fibre. It is expected that SPF which gave total digestion, should give the highest assays, and this is true for almost all of the elements. The exceptions are for $\mathrm{Cu}$ and $\mathrm{Mg}$ which returned highest values from HHM and AR respectively, though the values are close for all the three conditions. $\mathrm{Au}, \mathrm{Ag}$, Pd gave better assays with AR than HHM. Ag in particular is sparingly digesting under HHM with only $18.9 \mathrm{ppm}$ dissolved, compared with $849 \mathrm{ppm}$ in AR. For Pt, HHM appears to give better assay than with AR. For other elements, the assays from AR and HHM are comparably close within the possibility of sampling variations mentioned.

These observations confirms that printed circuit boards comminution fines wet a depend on the digestion condition, and second, that a single digestion condition cannot give best assays for all the elements combined. While SPF gave complete digestion, many elements could not be analysed from the resulting solution. Readings from the solutions from AR and HHM also does not distinctly give one condition as better than the other for all the elements. This reflects the heterogeneity of the sample as different chemical elements exhibit different activities at the chemical potential of a digestion system. In this context, the digestion condition giving the maximum assay value for a particular element can be considered as ideal for that element, and the assay obtained from that condition can be taken as most indicative of the absolute assay for that element in the fines sample. Assay from other digestion condition will only be a fraction of this absolute value. For elements such as Au, Ag, Pd and $\mathrm{Mg}$, AR condition - hot aqua regia digestion - gives the absolute assay, while for $\mathrm{Cu}, \mathrm{Sn}, \mathrm{Sb}$ and $\mathrm{Pt}$, for instance, the absolute assay is from HHM. 
Table 2

Assay values from ICP-OES + ICP-MS analyses of printed circuit boards comminution fines from different digestion conditions (mg/Kg).

\begin{tabular}{|c|c|c|c|}
\hline \multirow[t]{2}{*}{ Element } & \multicolumn{3}{|c|}{ Digestion condition } \\
\hline & AR: Aqua regia & HHM: $\mathrm{HNO}_{3}+\mathrm{HF}+$ microwave & SPF: $\mathrm{Na}_{2} \mathrm{O}_{2}$ fusion $+\mathrm{HCl}$ dissolution \\
\hline Au & 220 & 124 & \\
\hline $\mathrm{Ag}$ & 849 & 18.9 & \\
\hline $\mathrm{Al}$ & 32,900 & 32,890 & 32,922 \\
\hline As & 32.5 & N.D. & \\
\hline B & 10,800 & 9170 & \\
\hline $\mathrm{Ba}$ & 7590 & 8120 & 8140 \\
\hline $\mathrm{Bi}$ & 319 & 237 & \\
\hline $\mathrm{Ca}$ & 63,400 & 64,500 & 75,400 \\
\hline $\mathrm{Cd}$ & 17 & 11.2 & \\
\hline $\mathrm{Ce}$ & 72 & 48 & \\
\hline Co & 92.2 & 90.6 & \\
\hline $\mathrm{Cr}$ & 160.0 & 323 & 416 \\
\hline $\mathrm{Cu}$ & 42,700 & 43,200 & 42,800 \\
\hline $\mathrm{Fe}$ & 26,800 & 32,300 & 33,630 \\
\hline $\mathrm{Hf}$ & 10.4 & N.D. & \\
\hline K & 717 & 737 & \\
\hline La & 91.5 & 19.9 & \\
\hline $\mathrm{Li}$ & 40.3 & 39.7 & \\
\hline $\mathrm{Mg}$ & 2180 & 2130 & 2150 \\
\hline $\mathrm{Mn}$ & 1200 & 1230 & 1457 \\
\hline Mo & 53.7 & 40.1 & 138 \\
\hline $\mathrm{Na}$ & 2120 & 2050 & \\
\hline $\mathrm{Ni}$ & 1900 & 2110 & 2512 \\
\hline $\mathrm{P}$ & 1120 & 1110 & \\
\hline $\mathrm{Pb}$ & 23,100 & 22,300 & 23,530 \\
\hline Pd & 158 & 137 & \\
\hline $\mathrm{Pt}$ & 1.7 & 5.3 & \\
\hline$S$ & 555 & 2750 & \\
\hline $\mathrm{Sb}$ & 2620 & 3180 & \\
\hline $\mathrm{Se}$ & N.D. & N.D. & \\
\hline $\mathrm{Si}$ & 4070 & 11600 & 139,300 \\
\hline Sn & 29,100 & 29,800 & \\
\hline $\mathrm{Sr}$ & 785 & 686 & 780 \\
\hline $\mathrm{Te}$ & N.D. & N.D. & \\
\hline Th & 6.0 & 2.4 & \\
\hline $\mathrm{Ti}$ & 3340 & 4070 & 4168 \\
\hline $\mathrm{Tl}$ & N.D. & N.D. & \\
\hline $\mathrm{U}$ & 1.9 & 1.9 & \\
\hline V & 26.3 & 30.0 & 30 \\
\hline Y & 9.65 & 5.80 & \\
\hline $\mathrm{Zn}$ & 4890 & 5510 & 6212 \\
\hline $\mathrm{Zr}$ & 245 & 297 & \\
\hline
\end{tabular}

N.D. - Not detected.

An implication of these observations for a standard approach to eol printed circuit boards composition analysis is that absolute or actual assays of the constituent metallic elements will have to be combined from more than one digestion condition. However, except the objective of an analysis is purely on establishing the absolute assay, as in environmental concerns for hazardous constituents, this extensive routine may be unnecessary. In beneficiation investigations, valid inferences can be made based on relative assays of product streams obtained from one digestion condition, whether absolute assays were obtained for all target values or not. Also, assays from one digestion condition can be scaled up to the absolute obtainable by another, (for instance, Au reading from HHM can be scaled closer to the actual value obtained under AR) by using the assays ratio. It should be noted that such ratio should be confirmed for every batch of material.

It follows that, the final choice for a particular comminution fines analysis depends on the target elements and the analytical objective, whether comparative or absolute assaying. This implies that printed circuit boards wet analysis reports need to specify the digestion condition used, to help data interpretation and inferences. In any case, comparing the data from the three digestion conditions, hot aqua regia digestion appears best for general purpose analysis, in being able to be give analysis liquor for all the elements. The procedure is also less hazardous compared with using HF in HHM.

\subsection{Liberation analysis}

Fig. 1a-d shows dark field light optical micrographs of polished sections of the printed circuit boards comminution fines. Conservatively, the white particles are the more reflective metallic particles, while the black patches include organic particles. The glass fibres remain distinctly fibrous. The general morphology shows the metallic particles are present in very random shapes, indicative of various shearing, tensile and complex forces under which the comminution of the metallic particles were achieved. The glass fibres, on the other hand, notably produce particles well above the $\mathrm{dA}$ of $75 \mu \mathrm{m}$ in length.

In respect of liberation, Fig. 1a shows almost total liberation of all the particles in the $-75+38 \mu \mathrm{m}$ range, however a close up in Fig. 1b indicates some composite particles can still be found, although not very abundant: For $-38 \mu \mathrm{m}$ size particles, such composite particles could not be found on (four) polished sections at 100 and 200 times magnification (Fig. 1c and d).

SEM analysis provided a more qualitative assessment of the sections. It was confirmed that almost all the particles in the section 

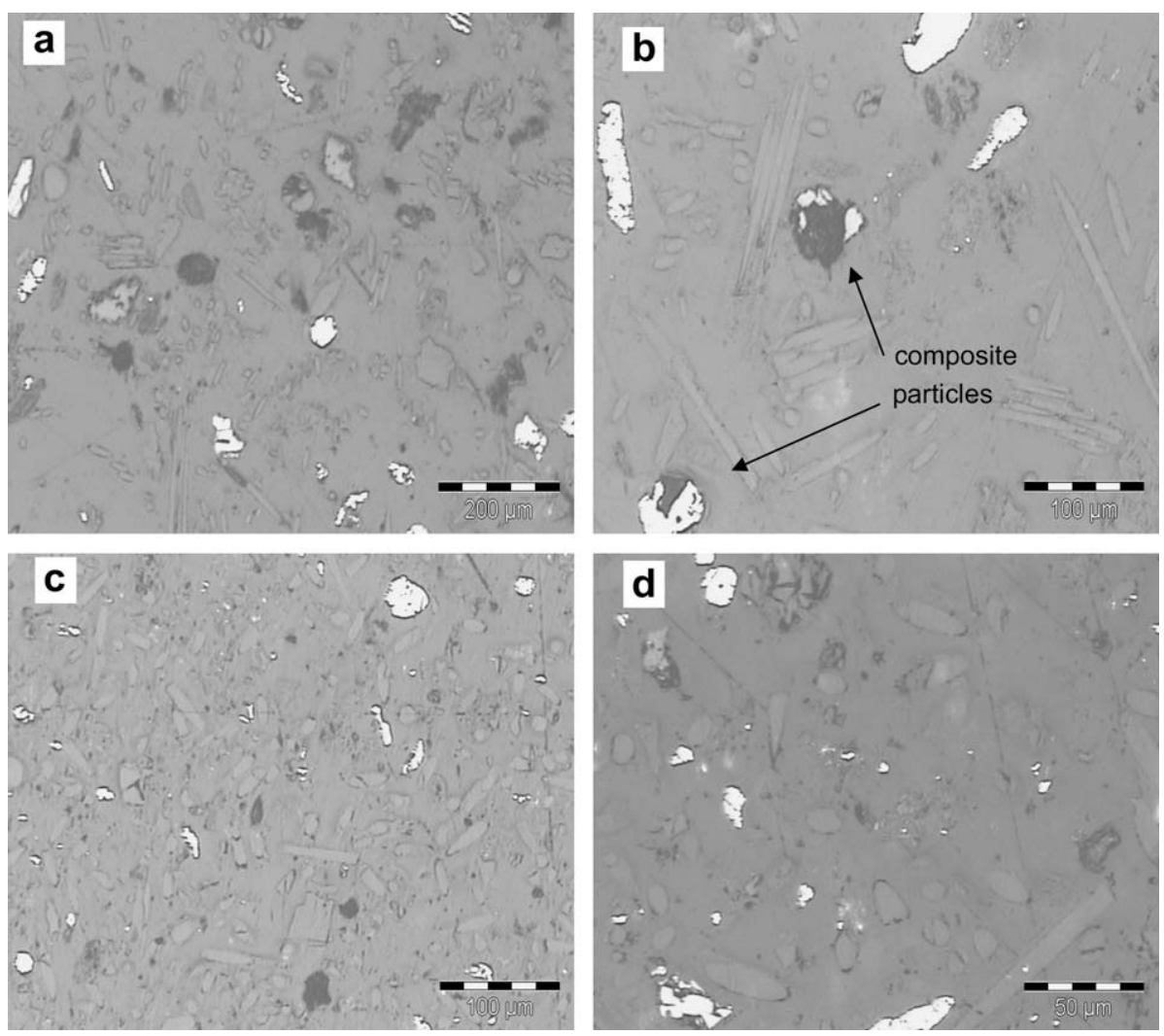

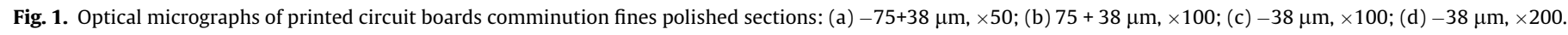

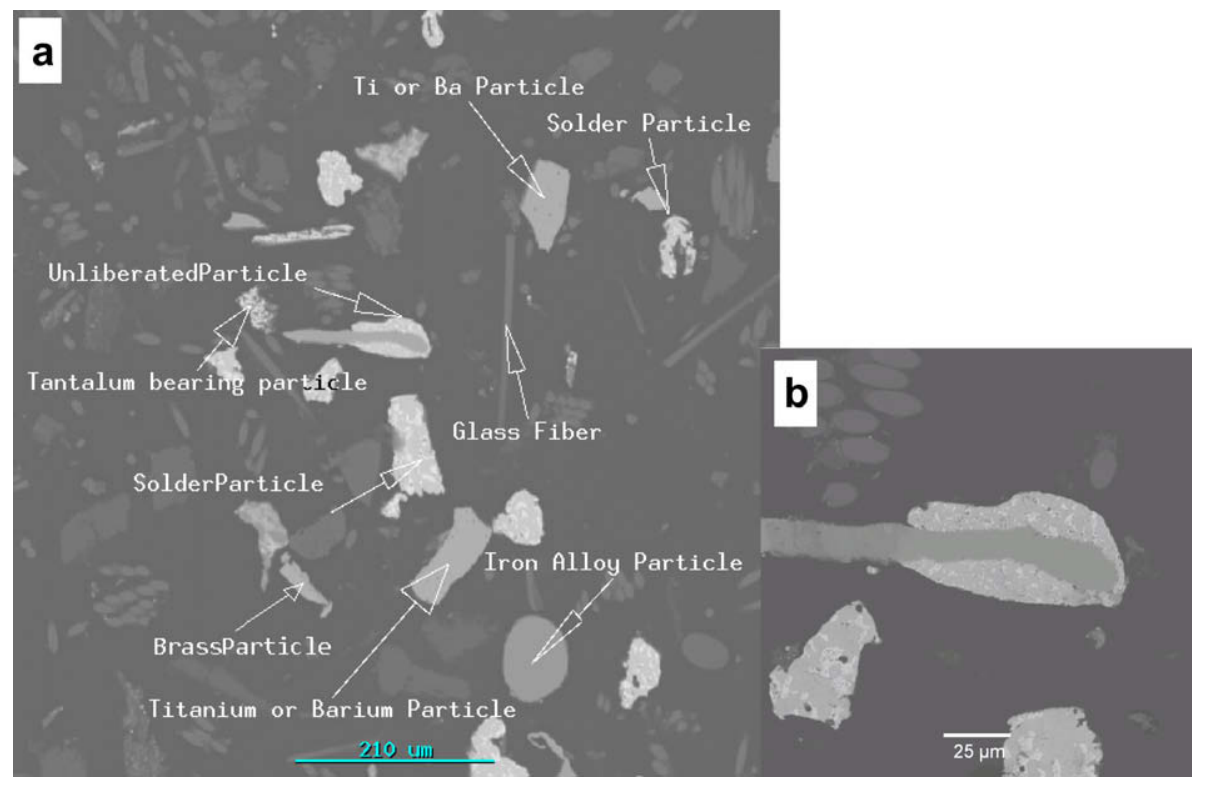

Fig. 2. SEM BSE images of $-75+38 \mu \mathrm{m}$ printed circuit boards comminution fines section (a), and a close up of an unliberated particle (b).

are unlocked, but unliberated particles could still be found (Fig. 2). A close up on such composite particle is shown in Fig. 2b. EDS analysis of the two distinct phases on this particle is contained in Table 3. From the composition and image, this particle appears to be a copper trace unliberated from solder. Averaged point counts of such composites relative to totally liberated particles on a number of sections gives a ratio of 1 to 194, implying a degree of liberation about $99.48 \%$. As the polished section may not be considered accurately representative of particles' relative abundance in the sample, this value may be taken only as an instance. The primary purpose here is to establish whether or not unliberated particles still exist at $-75 \mu \mathrm{m}$. On another note, although the degree of liberation can be taken as total, as it will be readily taken in conventional mineral processing, in a sample where compositions of the various constituents range from percentages to ppm, the little balance can be critical. In clearer perspective, the balance of about $0.5 \%$ is equivalent to about 5000 ppm composite particles. Assuming 100 of these are from the approximately $220 \mathrm{ppm}$ gold constituents, 
Table 3

SEM EDS composition analysis of phases in $-75+38 \mu \mathrm{m}$ printed circuit boards comminution fines polished section.

\begin{tabular}{|c|c|c|c|}
\hline Phases & Elemental lines & Atom (\%) & Element (wt\%) \\
\hline \multirow[t]{6}{*}{ Composite particle outer (Fig. 2b) } & $\mathrm{Al}-\mathrm{K}$ & 1.2 & 0.3 \\
\hline & $\mathrm{Sn}-\mathrm{L}$ & 82.1 & 77.0 \\
\hline & $\mathrm{Ca}-\mathrm{K}$ & 0.9 & 0.3 \\
\hline & $\mathrm{Cu}-\mathrm{K}$ & 1.9 & 1.0 \\
\hline & $\mathrm{Zn}-\mathrm{K}$ & 1.3 & 0.7 \\
\hline & $\mathrm{Pb}-\mathrm{L}$ & 12.7 & 20.8 \\
\hline \multirow[t]{4}{*}{ Composite particle inner (Fig. 2b) } & $\mathrm{Sn}-\mathrm{L}$ & 0.5 & 1.0 \\
\hline & $\mathrm{Ca}-\mathrm{K}$ & 0.2 & 0.1 \\
\hline & $\mathrm{Cu}-\mathrm{K}$ & 64.2 & 63.3 \\
\hline & $\mathrm{Zn}-\mathrm{K}$ & 35.1 & 35.6 \\
\hline \multirow[t]{8}{*}{ Ti-Barium particle (Fig. 2a) } & Co-L & 2.2 & 1.4 \\
\hline & $\mathrm{Al}-\mathrm{K}$ & 0.7 & 0.2 \\
\hline & $\mathrm{Si}-\mathrm{K}$ & 0.7 & 0.2 \\
\hline & $\mathrm{Ca}-\mathrm{K}$ & 2.3 & 1.0 \\
\hline & $\mathrm{Ba}-\mathrm{L}$ & 43.6 & 67.3 \\
\hline & $\mathrm{Ti}-\mathrm{K}$ & 44.5 & 24.0 \\
\hline & $\mathrm{Zn}-\mathrm{K}$ & 1.2 & 0.9 \\
\hline & $\mathrm{Zr}-\mathrm{K}$ & 4.8 & 4.9 \\
\hline \multirow[t]{4}{*}{ Fe alloy particle (Fig. 2a) } & $\mathrm{Al}-\mathrm{K}$ & 0.3 & 0.2 \\
\hline & $\mathrm{Si}-\mathrm{K}$ & 23.2 & 13.2 \\
\hline & $\mathrm{Mn}-\mathrm{K}$ & 0.7 & 0.8 \\
\hline & $\mathrm{Fe}-\mathrm{K}$ & 75.8 & 85.8 \\
\hline \multirow[t]{4}{*}{ Brass particle } & $\mathrm{Sn}-\mathrm{L}$ & 48.2 & 63.6 \\
\hline & $\mathrm{Fe}-\mathrm{K}$ & 0.8 & 0.5 \\
\hline & $\mathrm{Cu}-\mathrm{K}$ & 50.5 & 35.6 \\
\hline & $\mathrm{Zn}-\mathrm{K}$ & 0.4 & 0.3 \\
\hline
\end{tabular}

according to Table 2, then the response of gold may no longer be expected to be total in an applied minerals processing froth flotation operation.

Particle make up in the printed circuit boards comminution fines has important implications in beneficiation planning. Apart from existence of composite particles, EDS analysis of individual particles also show phases of alloyed metals. Table 3 shows the chemical compositions of some of the particles annotated in Fig. 2. This implies that beneficiation of this sample will at best produce fractions which are not cleaner than the alloys. For example, $\mathrm{Pb}$ would be inseparable from neither $\mathrm{Zn}$ nor $\mathrm{Sn}$ in a solder particle. A realistic pursuit will be to recover as much as possible of the metallic values in bulk into a product fraction.

\section{Conclusion}

Printed circuit boards comminution fines wet analysis assay is not only very dependent on the digestion condition, determination of absolute assays of all constituent elements will also require comparison of data from more than one digestion condition. However, if the analytical objective is a comparative assaying of samples from beneficiation treatments, aqua regia digestion can be recommended for most of the constituents. It gives a less hazardous procedure compared to $\mathrm{HF}+$ microwave $+\mathrm{HNO}_{3}$. It also give analysis liquor adequate for all the elements compared to $\mathrm{Na}_{2} \mathrm{O}_{2}$ fusion $+\mathrm{HCl}$ dissolution. Light microscope and SEM observations reveal that very few composite particles remain in the $-75+38 \mu \mathrm{m}$ fines sample. However, even the liberated particles themselves contain more than one chemical element, being metallic alloys. Beneficiation operation therefore can not attempt to separate such alloy particles into constituent elements; realistic schemes can aim only at achieving some bulk collection of metallic values into a concentrate.

\section{References}

ASTM Volume 03.05, October, 2007. Analytical Chemistry for metals, ores, and related materials: E 32 .

ASTM Standards: <http://www.astm.org/STORE/standardsearch.shtml>.

Babara, B.K., 2003. Preparation of samples for metal analysis. In: Somenath, M. (Ed.), Sample Preparation Techniques in Analytical Chemistry, Chemical Analysis: A
Series of Monographs on Analytical Chemistry and Its Application, 162. WileyInterscience, New Jersey, pp. 227-264.

Cui, J., Forssberg, E., 2003. Mechanical recycling of waste electric and electronic equipment: a review. Journal of Hazardous Materials B99, 243-263.

D'Silva, K., 2004. Brominated organic micropollutants - igniting the flame retardants issue. Critical Reviews in Environmental Science and Technology 34, 141-207.

Dunn, B.D., Nicholas, D., 1998. Elemental distribution of parts and materials making up of electronic box. Circuit World 24 (2), 23-25.

EU Directive - 2002/95/EC, 2003. Directive of the European parliament and of the council on the restriction of the use of certain hazardous substances in electrica and electronic equipment; Official Journal of the European Union, 13.2.2003: L37/19 EN.

Gomez, C.O., Strickler, D.W., Austin, L.G., 1984. An iodized mounting medium for coal particles. Journal of Electron Microscopy Technique 1, 285-287.

Goosey, M., Kellner, R.A., 2002. Scoping Study: End-of-life Printed Circuit Boards Department of Trade and Investment, Shipley Europe Limited.

Goosey, M., Kellner, R., 2003. Recycling technologies for the treatment of end of life printed circuit boards (PCBs). Circuit World 29, 33-37.

Henryk Matusiewicz, 2003. Wet digestion methods. Comprehensive Analytical Chemistry 41, 193-233.

Iji, M., Yokoyama, S., 1997. Recycling of printed wiring boards with mounted electronic components. Circuit World 23 (3), 10-15.

ISO 71.040.40. ISO Standards in Chemical Analysis, Including Analysis of Gases and Surface Chemical Analysis, published and under review.

Kim, B., Lee, J., Seo, S., Park, Y., Sohn, H., 2004. A process for extracting precious metals from spent printed circuit boards and automobile catalysts. JOM 56 (12), 55-58.

Kogan, V., 2006. Process for the Recovery of Precious Metals Scrap by Means of Hydrometallurgical Technique. Patent Application, WO 6006/013568 A3, 2006

Legarth, J.B., Alting, L., Danzer, B., Tartler, D., Brodersen, K., Scheller, H., Feldmann, K., 1995. A new strategy in the recycling of printed circuit boards. Circuit World 21 (3), 10-15.

Li, J., Puneet, S., Zong, G., Hong-Chao, Z., 2004. Printed circuit board recycling: a state of the art survey. IEEE Trans on Electronics Packaging Manufacturing 27 (1), 35-42.

Mou, P., Wa, L., Xiang, D., Gao, J., Duan, G., 2004. A physical process for recycling and reusing waste printed circuit boards. In: IEEE Conference Record, Internationa Symposium on Electronic and the Environment, May 2004, pp. 237-242. doi:10.1109/ISEE.2004.1299722.

Nourreddine, M., Björkman, B., Zhang, S., Forssberg, E., 1998. In: Mishra, B. (Ed.), Thermodynamic Conditions for the Formation of Dioxin during the Recycling Of Non-Ferrous Metals from Electric and Electronic Scrap, EPC Congress 1998. The Minerals, Metals and Materials Society.

Ogunniyi, I.O., Vermaak, M.K.G., 2007. Improving printed circuit board physical processing - an overview. In: Proceedings of European Metallurgical Conference, June 11-14, 2007. Dusseldorf, Germany, pp. 1645-1656.

Ogunniyi, I.O., Vermaak, M.K.G., 2009. Froth Flotation for Beneficiation of Printed Circuit Boards Comminution Fines: An Overview. Mineral Processing and Extractive Metallurgy Review 30 (2), 101-121.

Sander, S., Schubert, G., Jackel, H.-G., 2004. The fundamentals of the comminution of metals in shredders of the swing-hammer type. International Journal of Mineral Processing 74S, 385-393. 
Schubert, G., Bernotat, S., 2004. Comminution of non-brittle materials. International Journal of Mineral Processing 74S, S19-S30.

Shuey, S.A., Vildal, E.E., Taylor, P.R., 2006. Pyrometallurgical Processing of Electronic Waste. SME Annual Meeting, March 27-29, 2006, St. Louis, MO. Preprint 06037.

Sum, E.Y.L., 1991. The recovery of metals from electronic scrap. JOM 1991 (April) $53-60$.

Wen, X., Duan, C., Jiao, H., Zhao, Y., Zhou, X., Song, S., 2005. Study on metal recovery from discarded printed circuit boards by physical methods. In: Proceedings of IEEE International Symposium on Electronics and the Environment, 16-19 May, 2005, pp 121-128.
Willard, H., Merritt, L.L., Dean, J.A., Settle, F.A., 1988. Instrumental Methods of Analysis, seventh ed. Wardsworth Inc., California.

Wills, B.A., 1997. Mineral Processing Technology, sixth ed. Butterworth-Heinemann Publisher, Great Britain.

Zhang, S., Forssberg, E., 1997. Mechanical separation-oriented characterization of electronic scrap. Resource, Conservation and Recycling 21, 247-269.

Zhang, S., Forssberg, E., 1999. Intelligent liberation and classification of electronic scrap. Powder Technology 105, 295-301.

Zhao, Y., Wen, X., Li, B., Tao, D., 2004. Recovery of copper from printed circuit boards. Minerals and Metal Processing 21 (2), 99-102. 